\title{
ECONOMICS AND SOCIAL CHARACTERISTICS OF REGISTERED POULTRY EGG PRODUCERS IN ILORIN, KWARA STATE
}

\author{
Nurudeen Ayoyinka Jatto, Researcher \\ Usmanu Danfodiyo University, Sokoto, Nigeria \\ E-mail: nuayjao@yahoo.com
}

Received November 1, 2012

\begin{abstract}
The paper analyzed the economics and social characteristics of registered poultry egg producers in Ilorin, Kwara State. Primary data was used for the study. The data was collected using structured questionnaires administered to 150 stratified sampled registered poultry egg producer. Both descriptive and gross margin analysis were employed to analyze the data. Socio-economic analyses revealed that $68.7 \%$ of the poultry egg farmers were males with a mean age of 40 years and $78 \%$ having tertiary education with a mean year of poultry experience of $7 y e a r s .76 .7 \%$ were married with a mean family size of 4. Majority (53.3\%) of the farmers were civil servant with a mean farm size of 334 number of birds and 50\% of the farmers have been participating in cooperative society for over 6 to 10 years with majority (84.7\%) having no extension contact. The gross margin calculated shows that the farms had an average margin of $\mathrm{\#} 3,652$ per bird per year and the net average revenue of $\$ 3,024$ per bird per year showing that poultry egg production is profitable. It was recommended that government should endeavour to subsidize inputs such as feed ingredients and this can be achieved through poultry farmer's participation in crop production.
\end{abstract}

\section{KEY WORDS}

Economics; Social characteristics; Registered poultry egg.

In Nigeria, the livestock sector is an important component of the agricultural economy that provides animal protein to the populace as well as employment for a considerable percentage of the population (Oyesola and Olujide, 2000). In the humid south, over $85 \%$ of rural families keep small ruminants and local fowls primarily as an investment and sources of manure or meat at home or during festivals (Okoli, 2003). Demand for animal products in the country however continues to rise and is driven by improvements in personal income, population growth and increasing urbanization (Delgado et al., 1998). According to Okoli et al., (2004) there is need for improvement in livestock production systems in Nigeria and it could begin with the reorientation of graduates on the need to get involved in agrolivestock business as a form of self employment. The most recent step taken by the Federal Government of Nigeria is the ban on importation of frozen chicken and turkey parts, which aims at encouraging massive livestock production locally. The most common livestock production practiced in rural areas of Nigeria is poultry keeping
(Okoli et al., 2004) This business is attractive because birds are able to adapt easily, have high economic value, rapid generation time and a high rate of productivity that can result in the production of meat within eight weeks and first egg within eighteen weeks of the first chick being hatched (Okoli et al., 2004).poultry comes fourth among sources of animal proteins for human consumption in Nigeria and contributes about $10 \%$ of the national meat production (Adu et al.,1996). There is scarcity of published information on the economics and social characteristics of poultry business enterprises in Nigeria generally (Okoli et al., 2004). Such up to date information needed for policy formulation on the poultry sector is particularly lacking for kwara state. In recent times, poultry farmers in Nigeria have been suffering setbacks caused by rising cost of feeds and other inputs, significantly reducing net returns from these businesses (Aihonsu, 1999). The subject of economic analysis of poultry production in Nigeria has received considerable attention in the literature (Sani et al., 2000; Umeh and Odo, 2002; Olarinde and Kuponiyi, 2004; Adebayo 
and Adeola, 2005; Ekunwe et al., 2006; Amos, 2006 and Okafor et al., 2006; Oladeebo and Ambe-Lamidi, 2007).This study therefore investigate the economics and social characteristics of registered poultry egg business enterprises practitioners in Ilorin, Kwara State.

\section{METHODOLOGY}

The study was carried out in Ilorin, the capital city of Kwara state. Ilorin city consist of three local Government areas namely: Ilorin west, Ilorin south and Ilorin east. Kwara state was created on the 27th may, 1967 as one of the 12 states that replaced the former four regional structures of the country. Ilorin had an estimated population of about 847,582 people as of 2006 (NPC, 2007). The major ethnic groups are the Yoruba, the Hausa, the Fulani, the Babura and the Nupe people and the occupations of the people in the metropolis are craftwork, carving, cloth weaving and to a greater extent farming. Trading and poultry keeping are flourishing business of the people.

The study area was divided into three: Ilorin south, Ilorin east and Ilorin west, chosen based on predominance of registered poultry farmers as contained in the information from poultry association of Nigeria (PAN), Kwara State chapter. These three divisions have the highest percentage share of poultry farmers in the state. A stratified random sampling technique was adopted in selecting 50 registered poultry egg respectively from each division to make up a sample size of 150 registered poultry egg used for the analysis. The Data was obtained through a structured questionnaire and administered to the sampled farmers. Secondary information was obtained from journals, previous work and textbook.

Data analysis was done using Descriptive statistics and gross margin analysis. The mathematical notation for gross margin is presented as:

$$
\begin{aligned}
& \mathrm{GM}=\mathrm{TR}-\mathrm{TVC} \\
& \mathrm{GM}=\text { Gross Margin }(\AA) \\
& \text { TR=Total Revenue }(\#) \\
& \text { TVC= Total Variable Cost }(\#)
\end{aligned}
$$

\section{RESULT AND DISCUSSION}

\section{Social characteristics.}

Sex. The result shows that majority of the farmers are males. This high proportion of males to females may be because religion and custom play crucial roles in the livelihoods of the people in the study area that males are to provide for the household. The implication of male dominance may also be that productivity is expected to be higher because males have tendency to be more labour efficient. Taking labour efficiency into concern, this findings support Reddy et al., (2008) that three women are equivalent to two men.

Age. The result shows that majority of the farmers are relatively young and are still in their active age. The implication is that younger farmers are likely to adopt new innovation faster than the older ones. The finding is in agreement with Sani et al., (2007) that majority of farmer within the age range of 41 to 50years are still in there active age and more receptive to innovation.

Educational level. The result shows that majority of the poultry farmers had tertiary education meaning that they are highly educated. It is expected that the level of education will contribute significantly to decision making of a farmer. This findings support Obinne, (1991); Alabi and Aruna (2006) and Ndahitsa, (2008) that level of education determines the quality of skills of farmers, their allocative abilities and how well informed they are to the innovations and technologies around them. Also support the result of Oladipo and Adekunle (2010) that individuals with higher educational attainment are usually being faster adopters of innovation.

Poultry experience. The findings support Oluwatayo et al., (2008) that farmers with more experience would be more efficient, have better knowledge of climatic conditions and market situation and are thus, expected to run a more efficient and profitable enterprise. Also support the finding of Onyebinama (2004), that previous experience in farm business management enable farmers to set realistic time and cost targets, allocate, combine and utilize resources efficiently and identify production risks.

Marital status. The result shows that majority $(76.7 \%)$ of the farmers were married. This shows that the respondents are responsible according to the societal standard and therefore are likely to have some experience of life. This findings support the result of Oluwatayo et al., (2008) that married farmers tend to have large family to compliment family labour to enhance production and reduce the cost of hired labour. 
Table 1 - Socio-economic characteristics of poultry egg farmers

\begin{tabular}{|l|l|l|}
\hline & \\
\hline
\end{tabular}

Family size. The result shows that most of the farmers have family size range from 0 to 4 in numbers. The implication is that the farmer will spend less on feeding, education, health care and other living expenses on their dependants. These expenses may account for high savings at the end of every harvest season.The finding back up the result of Igodan et al., (1988) that more educated farmers tends to have smaller families and Arthur (2006) observed that small family size enjoy better economic and social lives which have great influence on better understanding of environmental conditions.
Main occupation. The result shows that majority of the farmers are civil servants. This indicates that poultry farming is a part time job in the study area and that most farmers do not depend on the business as the sole mean of livelihood. This may be due to the fact that farmers usually want to add to their farm earnings. This result agrees with the findings of Amaza (2000). That it is common for some farm household to engage in other non farming activities to complement their earnings from farming occupation for their livelihood.

Cooperative society. The result shows that majority of the farmers have been participating in cooperatives society for over 6 to 10 years. The implication of this result is that majority of the farmers have access to credit facilities from among the cooperative society they belong to enhance their production and productivity in terms of sourcing for credit or other sundries to boost their productivity. It also helps them share information and project a collective demand.

Extension contact. The result indicated that majority of the farmers do not have any form of extension contact. The implication of the finding shows that extension contact which is a channel through which agricultural innovations and information are passed to farmers for improvement in their standard of living, production and productivity are missing. This can bring about low productivity due to lack of innovative information.

Profitability assessment of poultry egg farmer in the study area. Table 2 shows the gross margin analysis of poultry egg farmers per bird. The cost item section showed that feeding has the highest contribution to the cost of production with $79.53 \%$. The Table also revealed that fixed cost items is contributing second highest with $11.99 \%$ and stocking which is the most important cost of production is contributing third highest with $3.97 \%$.This is followed by medication, transportation and labour contributing $1.19 \%, 1.83 \%$ and $0.76 \%$ respectively. The revenue items also revealed that egg is contributing higher than spent layer at $91.91 \%$ while the spent layer is contributing $8.09 \%$.

The findings showed that the total variable cost constitute the highest proportion $(88 \%)$ of the total cost of production. Cost of feeding alone accounted for $79.53 \%$ of the total cost of production. Implying that feeding is an essential cost variable in poultry production. This agrees with 
Intisar (1995); Sharabeen (1996); Yusuf and Malomo (2007) and Adepoju (2008) that feed cost comprises the highest share in the total cost of poultry production.

Table 2 - Average cost and revenue of poultry egg farmers per bird

\begin{tabular}{|c|c|c|}
\hline Cost items & Amount (N) & Percentage \\
\hline Feeding & 4164 & 79.53 \\
\hline Labour & 40 & 0.76 \\
\hline Medication & 100 & 1.91 \\
\hline Transportation & 96 & 1.83 \\
\hline Stocking & 208 & 3.97 \\
\hline Total variable cost & 4608 & 88.00 \\
\hline Fixed cost & 628 & 11.99 \\
\hline Total cost & 5236 & 100 \\
\hline \multicolumn{3}{|l|}{ Revenue items } \\
\hline Egg & 7592 & 91.91 \\
\hline Spent layer & 668 & 8.09 \\
\hline Total revenue & 8260 & 100 \\
\hline Gross margin & 3652 & - \\
\hline Net revenue & 3024 & - \\
\hline
\end{tabular}

Source field survey 2012

The result also showed that majority of the revenue is generated through the sale of eggs. This is similar to the findings of Narahari (2002); Rajendran and Samarendu (2003) and Emam and Hassan (2010) who found that sale of eggs account for approximately $85 \%$ of total revenue in poultry egg production. The findings also support the result of Intisar (1995); Sharabeen (1996); Yusuf and Malomo (2007) and Adepoju (2008) that sale of egg contributed highest share to total revenue. The result further showed that the average gross margin per bird was $\$ 3652$ and net revenue was $\$ 3024$. This implies that poultry egg production was profitable in the study area. The result agrees with the findings of Reddi (1986) and Rajendran and Samarendu (2003) who found that gross margins and net returns increases with increase in farm size and was profitable. It also agrees with the result of Yusuf and Malomo (2007); Sani et al., (2007) and Rajendran and Samarendu (2003) that many factors affect the profitability of a particular poultry farm size which may include cost of birds, price of egg among others depending on farm location.

\section{CONCLUSION}

Cost of feeding constitutes a major problem to most of the poultry farmers as it accounts for a larger percentage of total cost of production, since poultry birds cannot do without food. Despite complains of poultry egg farmers on the rapid increase in price of feed ingredient. The poultry egg producers still benefit from egg production in form of income and egg farming is profitable in the study area. Majority of the poultry egg farmers identified high cost of production especially cost of feed ingredients as their major constrain: Therefore, government should endeavour to subsidize inputs such as feed ingredients and this can be achieved through poultry farmer's participation in crop production.

\section{REFERENCES}

Adebayo, O.O. and R.G. Adeola (2005). SocioEconomic Factors Affecting poultry Farmers in Ejigbo Local Government Area of Osun State, Journal of Hum. Ecol., 18:3941.

Adepoju, A. A. (2008). Technical efficiency of Egg Production in Osun state, International journal of Agricultural Economics and $\mathrm{Ru}-$ ral Development: (1) 7-14.

Adu, I. F., Aina A. B. and Okeleye, K. A. (1996). On farm establishment of productivity of Gmelina and Gliricidia as browse for goats Nigerian Journal of Animal Production, 23 (1): 47-52.

Aihonsu, J.O.Y. (1999). Optimal laying period for profitable and sustainable egg produc- tion: in Bamiro, O. M. and Shittu A. M. (2009). Vertical Integration and Cost Behavior in poultry Industry in Ogun and Oyo States of Nigeria.

Alabi, R.A. and M.B. Aruna (2006). Technical Efficiency of Family Poultry Production in Niger Delta, Nigeria, Journal Central European Agriculture 6(4) 531-538.

Amaza, P.S. (2000). Resource Use Efficiency in Food Crop Production in Gombe State: A $\mathrm{PhD}$ Thesis (unpublished) cited in Abdulsalam R.Y. (2010). Economics of Smallholder Irrigated Farming System in the Hadejia Nguru Wetlands of North Eastern Nigeria. M.sc dissertation (unpublished).Department of Agricultural Economics and Extension, 
Faculty of Agriculture, Usmanu Danfodiyo University Sokoto.

Amos, T.T. (2006). Analysis of Backyard poultry Production in Ondo State, Nigeria, Int. J. Poult. Sci., 5: 247-250.

Arthur, J. (2006). Family Size and Quality of Life Nexus: A Case of the Sunyani Municipality, Ghana. Paper Presented at the 5th African Population Conference, Arusha, Tanzania 10th-14th December, 2007.

Delgado, C. L., Courbois, C. B. and Rosegrant, M. W. (1998). Global food demand and contribution of livestock as we enter the new millennium; in M Gill, T Smith, G E Pollott, E Owen and T L J Lawrence (eds.) Food, lands and livelihoods Setting research agendas for animal science. BSAS Occasional Publication 21. 27-42.

Ekunwe, P.A., O.O. Soniregun and J.O. Oyedeji (2006). Economics of Small Scale Deep Litter System of Egg Production in Oredo Local Government Area of Edo State, Nigeria, Int. J. Poult. Sci., 5: 81-83.

Emam, A.A. and A.M. Hassan (2010). Economics of egg poultry production in Khartoum State with emphasis on the open-systemSudan; African Journal of Agricultural Research Vol. 5(18), pp. 2491-2496.

Igodan, C.O., P.E. Ohaji and J.A. Ekpere (1988).Factors Associated with the Adoption of Recommended Practices for Maize Production in Kainji Lake Basin of Nigeria Agricultural Administration and Extension. 29:149-156.

Intisar, Y.A. (1995). The economics of poultry production in Khartoum State: M.Sc. Thesis University of Khartoum Faculty of Agriculture, Department of Agriculture Economics. Cited in Emam, A.A. and A.M. Hassan (2010). Economics of egg poultry production in Khartoum State with emphasis on the open-system- Sudan; African Journal of Agricultural Research Vol. 5(18), pp. 24912496.

Narahari, D. (2002). All Layer Farms is More Economical than Chick, Grower Cum Layer Farm, Department of poultry science, Madras veterinary college, India. Cited in Rajendran, K. and M. Samarendu (2003). Comparative Economic Analysis and Constraints in Egg Production under Cage vs. Deep Litter Systems of Rearing in India, International Journal of Poultry Science 2 (2): 153-158.
National Population Commission (NPC), (2007). Population Census Data Ilorin, Kwara State, Nigeria, Federal Republic of Nigeria Official Gazette, National and State Provisional Total Census, Printed and Published in 2007 by Federal Government Printer, Lagos, Nigeria. No 21 vol.94, pp 175-200.

Ndahitsa, M.A. (2008). Impact of Small Scale Irrigation Technologies on Crop Production by Fadama users in Niger state, 10th national Annual Conference of National Association of Agricultural Economics (NAAEC).Held at university of Abuja main campus $\mathrm{p} 195$.

Obinne, C.P.O. (1991).”Adoption of Improved Cassava Production Technologies by Small Farmers in Bendel State" African journal of Biotechnology 7 (9): 1227-1286.

Okafor, F.C and G.O. Andrew (1994). Rural Systems and Land Resources Evaluation for Africa: Cited in Abdulsalam R.Y. (2010). Economics of Smallholder Irrigated Farming System in the Hadejia Nguru Wetlands of North Eastern Nigeria. M.sc Dissertation (unpublished). Department of Agricultural Economics and Extension, Faculty of Agriculture, Usmanu Danfodiyo University Sokoto.

Okafor, R.M., M.A.C.A. Odii, C.A. Emeyonu and U. Obih, (2006). Profitability Analysis of poultry Production Imo State, Nigeria. In Adepoju, S.O., and P.B.Okunneye (eds). 2006. Proceedings of the 20th Annual National Conference of Technology and Agricultural Development in Nigeria. 18th-21st Sept. 2006. Forestry Research Institute of Nigeria, Federal College of Forestry, Jos, Nigeria, pp: 392-397.

Okoli ,I. C., C. N. Anyaegbunam, E. B. Etuk, M. C. Uchegbu, and A. B. I. Udedibie (2004). Socio Economic Characteristics of Poultry Business Entrepreneurs in Imo State, Nigeria. Journal of agriculture and social research vol. 4, no. 2, 2004.

Okoli, 1. C. (2003). Incidence and modulating effects of environmental factors on trypanosomiasis, peste des petit (PPR) ruminants and bronchopneumonia of West African dwarf goats in Imo state, Nigeria. Livestock Research for Rural Development, 15 (9), http://www.utafoundationorg.

Oladeebo, J.O. and A.I. Ambe-Lamidi (2007). Profitability, Input Elasticities and Economic Efficiency Of Poultry Production Among 
Youth Farmers In Osun State, Nigeria, International Journal Of Poultry Science 6 (12): 994-998.

Oladipo, F and O. Adekunle (2010). Empirical Determination of Socio-economic Status and its Relationship with Selected Characteristics of Rural Male Farmers in Kwara state, Nigeria. A Research Journal of Agriculture and Biological Sciences, 6(1):64-76, 2010.

Olarinde, L.O. and F.A. Kuponiyi, (2004). Resource Productivity among Poultry Farmers in Oyo State, Nigeria: Implications For Agricultural Development. J. Sustainable Dvpt., 1: 20-26.

Oluwatayo, I.B., A.B. Sekumade and S.A. Adesoji (2008). Resource use Efficiency of Maize Farmers in Rural Nigeria. Evidence from Ekiti State, World journal of agricultural science 4(1): 91-99.

Onyebinama, U.A.U., (2004). Farm Business Management for Smallholder Farm Firms in Nigeria, Owerri Alphabet Nigeria Publishers, Nigeria.

Oyesola, O.B. and Olujide, M.G. (2000). Participation of livestock farmers in Nigerian,Agricultural insurance scheme. A case study of Iseyin L. G. A. Proceedings of Animal Science Association of Nigeria Conference, Port Harcourt Sept. 19-22, Pp. 213.

Poats, S.V. (1991). The Role of Gender in Agriculture Development cited in Yisehak, K., (2008) Gender Responsibility in Small Holder Mixed Crop-Livestock Production Systems in Jimme Zone, South West Ethiopia. Livestock Research for Rural Development 20(1):1-20. Retrieved on June 28, 2012 from http://www.irrd.org.

Rajendran, K. and M. Samarendu (2003). Comparative Economic Analysis and Constraints in Egg Production under Cage vs. Deep Litter Systems of Rearing in India, International Journal of Poultry Science 2 (2): 153-158.

Reddi, R. P. (1986). Studies on the Performance of Different Commercial Strains, (Layer) Under Field Condition, (Unpublished Ph.D. Thesis, Department of Poultry Science, Madras Veterinary College, Chennai), P:75. Cited in Rajendran, K. and M. Samarendu (2003).Comparative Economic Analysis and Constraints in Egg Production under Cage vs. Deep Litter Systems of Rearing in
India, International Journal of Poultry Science 2 (2): 153-158.

Reddy, S.S., P.R. Ram, T.V. Neelakanta-Sastry and I.B. Deri (2008). Agricultural Economics Oxford and IBH Publishing Co. PVT Ltd, New Delhi, 646 pp. Cited in Abdulsalam R.Y. (2010). Economics of Smallholder Irrigated Farming System in the Hadejia Nguru Wetlands of North Eastern Nigeria. M.sc dissertation (unpublished).Department of Agricultural economics and Extension, Faculty of Agriculture, Usmanu Danfodiyo University Sokoto.

Sani, R.M., I. Tahir and S. Kushwaha, (2000). Economics of poultry Production in Bauchi State: A Case Study of Bauchi Local Government Area. Nig. J. Anim. Prod., 27: 109113.

Sani, R.M., S.A., Musa, M.I. Daneji, M.T. Yakasai and O. Ayodele (2007). Cost and Returns Analysis in Poultry Production in Bauchi and Gombe metropolis area. Continental Journal of Agricultural Economics 1:14-19.

Sharabeen, I.E. (1996). Economics of poultry industry in Khartoum State: M.Sc. Thesis University of Khartoum Faculty of Agriculture, Department of Agriculture Economics. Cited in Emam, A.A. and A.M. Hassan (2010).Economics of egg poultry production in Khartoum State with emphasis on the open-system- Sudan; African Journal of Agricultural Research Vol. 5(18), pp. 24912496.

Simsek, D. and O. Karkacur (1996). A Study on Socio-Economic Factors Affecting the Adoption of Agricultural Innovations in Rural Regions. Paper presented at the 15th International Congress of Mediterranean Federation for Health and Production of Ruminants.15th-19th May 1996.

Umeh, G.N. and B.I. Odo, 2002, Profitability of Poultry Production among School Leavers in Anaocha Local Government Area (LGA) of Anambra State, Nigeria, Nig. J. Anim. Prod., 29: 76-80.

Yusuf, S.A. and O. Malomo (2007). Technical Efficiency of Poultry Egg Production in Ogun State: A Data Envelopment Analysis (DEA) approach. International journal of poultry science 6(9):627-629. 